Aus Tab. 4, in der die beobachteten und die berechneten $G(v)$-Werte gegenübergestellt sind, ersieht man, daß die Übereinstimmung vorzüglich ist.

\begin{tabular}{rcrrrr}
\hline$v$ & $G(v)_{\text {beob. }}$ & \multicolumn{1}{c}{$\Delta G_{v+1 / 2}$} & $-\Delta_{2} G$ & $G(v)_{\text {ber. }}$ & Diff. \\
\hline 0 & 0 & 1036,58 & & $-0,06$ & 0,06 \\
1 & 1036,58 & & 57,06 & 1036,50 & 0,08 \\
2 & 2016,10 & 979,52 & 46,15 & 2016,33 & $-0,23$ \\
3 & 2949,47 & 933,37 & 38,45 & 2949,44 & 0,03 \\
4 & 3844,39 & 894,92 & & 3844,32 & 0,07 \\
\hline
\end{tabular}

Tab. 4. Schwingungsniveaus des $\mathrm{B}^{3} \Pi_{\mathrm{g}}$-Terms in $\mathrm{cm}^{-1}$.

Der Limes von $18917 \mathrm{~cm}^{-1}$ wird für $v=39 \mathrm{er}$ reicht. Eine Fehlerabschätzung hat in diesem Fall keine so große Bedeutung wie für den $\mathrm{A}^{3} \Pi_{\mathrm{g}}$-Term, weil das Gleichungssystem unterbestimmt war.

Herrn Hochschuldozenten Dr. H. Krempl, Physikalisch-Chemisches Institut der Technischen Hochschule München, sind wir für die aktive Unterstützung dieser Arbeit zu großem Dank verpflichtet. - Ebenso gilt unser Dank Herrn o. Prof. Dr. F. Dörr für sein Interesse
Nimmt man die Dissoziation des $\mathrm{B}^{3} \Pi_{\mathrm{g}}$-Terms zu $\mathrm{C}\left({ }^{3} \mathrm{P}\right)+\mathrm{C}\left({ }^{1} \mathrm{D}\right)$ an, so ergibt sich für $D_{0}\left(\mathrm{C}_{2}\right)$ :

$$
\begin{array}{rr}
\text { Extrapolation: } & 18917 \mathrm{~cm}^{-1} \\
v_{00}: & 39806 \mathrm{~cm}^{-1} \\
\mathrm{X}^{\prime}{ }^{3} \mathrm{X}_{\mathrm{u}}-\mathrm{x}^{1} \Sigma_{\mathrm{g}}^{+}: & 610 \mathrm{~cm}^{-1} \\
\hline \mathrm{C}\left({ }^{1} \mathrm{D}\right)-\mathrm{C}\left({ }^{3} \mathrm{P}\right): & 101933 \mathrm{~cm}^{-1} \\
\hline D_{0}\left(\mathrm{C}_{2}\right): & 49139 \mathrm{~cm}^{-1}
\end{array}
$$

Diesem Wert von 6,09 eV für die Dissoziationsenergie des $\mathrm{C}_{2}$-Moleküls kommt natürlich nicht die Bedeutung des in Abschnitt 3 erhaltenen Wertes zu. Es konnte jedoch gezeigt werden, daß sich die Schwingungsniveaus des $\mathrm{B}^{3} \Pi_{\mathrm{g}}$-Terms ebenfalls durch die Formel (5) darstellen lassen und daß der erhaltene Wert für $D_{0}\left(\mathrm{C}_{2}\right)$ nicht im Widerspruch zu dem aus der Konvergenz des $\mathrm{A}^{3} \Pi_{\mathrm{g}}$-Terms erhaltenen Wert steht.

an den aufgezeigten Problemen. - Die Anregung zu dieser Untersuchung geht auf Herrn Prof. Dr. P. H. Brodersen $\dagger$ zurück, an dessen Institut für Spektroskopie und Molekularstrahltechnik (DVL-Stuttgart) diese Arbeit begonnen wurde.

\title{
Water Solubility in Molten Alkali Nitrates*
}

\author{
Giuseppe Bertozzi * \\ Electrochemistry Group, Euratom C.C.R., Petten, Holland \\ (Z. Naturforschg. 22 a, 1748-1751 [1967] ; received 3 July 1967)
}

\begin{abstract}
The solubility of water vapor in pure lithium nitrate and in lithium--sodium and lithium-potassium nitrate mixtures, at water vapor pressures up to 30 torr and temperatures $230-280^{\circ} \mathrm{C}$ is reported.

The dissolution process is reversible, i. a. no hydrolysis reactions occur.

The ion-dipole interaction energy is taken into account, and it is shown to be the most relevant parameter in determining the dissolution process.

Thermodynamic quantities for the solution equilibrium are given.
\end{abstract}

Water vapor dissolves appreciably in some fused salts; nevertheless, quantitative information on the topic is still very scanty, and even the nature of the dissolution process is not fully elucidated ${ }^{1-3}$.

Small solubilities have been found for inert gases in molten halides ${ }^{4,5}$ : in this case the free energy

* Paper presented at the San Francisco Meeting of the Electrochemical Society - San Francisco (California) May 9/13, 1965.

* Present Adress: Euratom C.C.R., Ispra, Italy.

1 F. R. Duke and A. S. Doan, Iowa State Coll. J. Sci. 32, 451 [1958].

2 J. P. Frame, E. Rhodes, and A. R. Ubbelohde, Trans. Faraday Soc. 57, 1075 [1961]. of the solution process has been equated to the free energy of formation of holes having the size necessary to accomodate the solute molecules.

In the present paper we report on water vapor solubilities in liquid alkali nitrates. Thermodynamic quantities for the dissolution process are discussed.

3 W. J. Burkhard and J. D. Corbett, J. Amer. Chem. Soc. 79, 636 [1957].

4 R. Grimes, V. Smith, and M. Watson, J. Phys. Chem. 62, 862 [1958].

5 M. Blander, R. Grimes, V. Smith, and M. Watson, J. Phys. Chem. 63, 1164 [1959]. 
The ion-dipole interaction energy is assumed to be the principal parameter in determining the equilibrium position.

\section{Experimental}

The apparatus consists of a thermobalance connected through a stopcock to a small water reservoir, kept in a thermostated bath. A vacuum line provides a pressure as low as $10^{-5}$ torr.

A crucible containing $3 \div 5 \mathrm{~g}$ of the salt under investigation is put on the balance; the furnace is then set in position and the salt is kept under high vacuum in the liquid state for many hours; then the vacuum line is cut off and water vapor allowed to enter the system; a few hours later, equilibrium is reached, and the weight increase gives directly the quantity of water which entered the melt.

The measurements were carried out in pure lithium nitrate, and in lithium-sodium and lithium-potassium nitrate mixtures, in the whole range of compositions, at $280{ }^{\circ} \mathrm{C}, 265^{\circ} \mathrm{C}$ and, where possible, $230^{\circ} \mathrm{C}$.

Pure sodium and potassium nitrates were not investigated because the water solubility in these salts is too low to be detected by this method.

The water vapor pressure ranged from 5 to 30 millimeters of mercury.

\section{Results}

Over the given pressure range the water vapor solubility is a linear function of its pressure (i. e. the Henry's law is obeyed) and decreases with increasing temperature.

We observed that water vapor dissolution in molten alkali nitrates is a true physical process, without any hydrolysis reaction. The process is always reversible: the equilibrium corresponding to a given vapor pressure can be reached by dissolving water in a dry melt as well as by removing water from a solution which was previously equilibrated at a higher vapor pressure. The melt can be hydrated and dried many times, and each time the same equilibrium composition is reached. This trend distinguishes the alkali nitrates from alkali halides, which undergo an irreversible hydrolysis reaction ${ }^{3}$.

Our experimental results are summarized in Table 1, where the Henry's constants are given in millimoles of water per mole of solvent per torr.

Concerning the dependence of the solubility on the solvent composition, we observed a linear relationship between the logarithm of the equilibrium constant and the solvent composition in molar fractions (Fig. 1); the equilibrium constant is here ex- pressed as the ratio between the water concentration (in moles/cc) in the liquid and vapor phases respectively.

This behaviour corresponds to that predicted for the solubility of gases in ideal mixtures of solvents ${ }^{6}$ :

$$
\log K=x_{\mathrm{A}} \log K_{\mathrm{A}}+x_{\mathrm{B}} \log K_{\mathrm{B}}+w x_{\mathrm{A}} x_{\mathrm{B}}
$$

where $K_{\mathrm{A}}$ and $K_{\mathrm{B}}$ are the Henry's constants for the pure solvents; $w$ accounts for the non-ideality of the mixture and vanishes in our case.

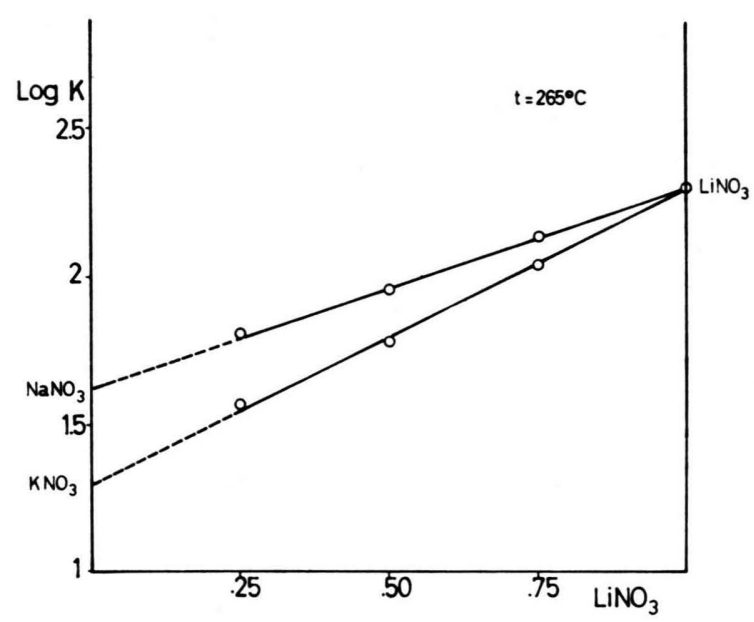

Fig. 1. The logarithm of the equilibrium constant is plotted against the molar composition of the solvent.

\begin{tabular}{|c|c|c|}
\hline $\begin{array}{l}\text { Solvent } \\
\text { mole } \%\end{array}$ & $\begin{array}{l}\text { Temperature } \\
{ }^{0} \mathrm{C}\end{array}$ & $\begin{array}{c}K \\
\text { millimoles } \mathrm{H}_{2} \mathrm{O}\end{array}$ \\
\hline $\begin{array}{l}\mathrm{LiNO}_{3} \\
\mathrm{LiNO}_{3} \\
\mathrm{LiNO}_{3} \mathbf{7 5} \%+\mathbf{K N O}_{3} \mathbf{2 5} \% \\
\mathrm{LiNO}_{3} \mathbf{7 5} \%+\mathbf{K N O}_{3} \mathbf{2 5} \% \\
\mathrm{LiNO}_{3} \mathbf{5 0} \%+\mathbf{K N O}_{3} \mathbf{5 0} \% \\
\mathrm{LiNO}_{3} \mathbf{5 0} \%+\mathbf{K N O}_{3} \mathbf{5 0} \% \\
\mathrm{LiNO}_{3} \mathbf{2 5} \%+\mathbf{K N O}_{3} \mathbf{7 5} \% \\
\mathrm{LiNO}_{3} \mathbf{2 5} \%+\mathbf{K N O}_{3} \mathbf{7 5} \%\end{array}$ & $\begin{array}{l}265 \\
280 \\
230 \\
265 \\
230 \\
265 \\
230 \\
265\end{array}$ & $\begin{array}{l}0.232 \\
0.165 \\
0.278 \\
0.137 \\
0.162 \\
0.082 \\
0.099 \\
0.054\end{array}$ \\
\hline $\begin{array}{l}\mathrm{LiNO}_{3} \mathbf{7 5} \%+\mathrm{NaNO}_{3} \mathbf{2 5} \% \\
\mathrm{LiNO}_{3} \mathbf{7 5} \%+\mathrm{NaNO}_{3} 25 \% \\
\mathrm{LiNO}_{3} \mathbf{7 5} \%+\mathrm{NaNO}_{3} \mathbf{2 5} \% \\
\mathrm{LiNO}_{3} \mathbf{5 0} \%+\mathrm{NaNO}_{3} \mathbf{5 0} \% \\
\mathrm{LiNO}_{3} \mathbf{5 0} \%+\mathrm{NaNO}_{3} \mathbf{5 0} \% \\
\mathrm{LiNO}_{3} \mathbf{5 0} \%+\mathrm{NaNO}_{3} \mathbf{5 0} \% \\
\mathrm{LiNO}_{3} \mathbf{2 5} \%+\mathrm{NaNO}_{3} \mathbf{7 5} \% \\
\mathrm{LiNO}_{3} \mathbf{2 5} \%+\mathrm{NaNO}_{3} \mathbf{7 5} \%\end{array}$ & $\begin{array}{l}230 \\
265 \\
280 \\
230 \\
265 \\
280 \\
265 \\
280\end{array}$ & $\begin{array}{l}0.354 \\
0.165 \\
0.118 \\
0.242 \\
0.110 \\
0.081 \\
0.084 \\
0.064\end{array}$ \\
\hline
\end{tabular}

Table 1.

6 O. Connell and M. Prausnitz, Ind. Eng. Chem. Fundamentals 3, 347 [1964]. 


\section{Discussion}

The straight line of $\log K$ as a function of the composition can be easily extrapolated up to zero content of lithium nitrate (Fig. 1: dotted part of the lines). So, we are able to calculate what would have been the water solubility in pure sodium and potassium nitrates, at $265^{\circ} \mathrm{C}$, if these were liquid at this temperature. These fictitious values will be compared with that for lithium nitrate at the same temperature, in order to have a set of data as a function of the cation size.

The thermodynamic quantities concerning the dissolution process at $265^{\circ}$ are summarized in Table 2 for the three pure alkali nitrates.

In column 2 the equilibrium constants are given, expressed as the ratio of concentrations of water molecules in the dissolved and gaseous states $\left(C_{\mathrm{d}} / C_{\mathrm{g}}\right)$.

In column 3 the standard free energies are reported. In column 4 the average heats of solution, calculated from the slope of the $\log K$ against $1 / T$, are given. The total entropy change associated to the equilibrium:

$$
\mathrm{H}_{2} \mathrm{O}\left(\mathrm{g}, C_{\mathrm{g}}\right) \rightleftarrows \mathrm{H}_{2} \mathrm{O}\left(\mathrm{d}, C_{\mathrm{d}}\right)
$$

is reported in column 5 ; the subscripts " $g$ " and " $d$ " denote gaseous and dissolved state, and $C_{\mathrm{g}}$ and $C_{\mathrm{d}}$ concentrations in gaseous and liquid phase, respectively.

In column 6 the entropy change associated with the isothermal compression of the vapor (considered as ideal) $\Delta S_{1}=-R \ln \left(C_{\mathrm{d}} / C_{\mathrm{g}}\right)$ is given; the difference $\Delta S_{2}=\Delta S-\Delta S_{1}$ (given in the last column) gives the entropy change associated to the transfer of a mole of water from the gaseous into the liquid phase, excluding the contribution due to the concentration change.

We see that this quantity is always negative, and its absolute value increases with decreasing cationic size: we may suppose that this trend is caused by the ionic field, which is so great that an arrangement of local order is set up.
The small ions, sodium and lithium, are known as "order-producing ions"; this property decreases with increasing ionic size. The variation of the entropy of solution towards less negative values with increasing cationic radius is a direct consequence of this "order-producing tendency".

We emphasize that the water vapor solubility in these liquids is much larger than that of non-polar gases $^{4,5}$ : this trend is likely to be related to the electrostatic interaction between solvent ions and solute dipoles. Since the energy of this interaction decreases with the square of the distance, and since nitrate anions are much larger than alkali cations, the size of these latter is the relevant parameter in determining the relative interaction energy.

The electrostatic energies of the alkali ions in the field of a water molecule were recently calculated by $\mathrm{V}_{\text {AsLow }}{ }^{7}$; this author, making two different assumptions on the symmetry of the electric field of the water molecule, gave two possible numerical values for the energy of each cation-water interaction.

We recall that the model used by VAsLow is essentially that of an ion and an adjacent water molecule in a vacuum. In a paper of Rirson and Hasted ${ }^{8}$ it is shown that in the neighbourhood of a pointcharge placed in a dielectric medium there is a region of complete dielectric saturation up to $2 \AA$, where the dielectric constant has a value of about four. Thus, we have divided the energies given by VASLow by this value of the dielectric constant, and have expressed the resulting values in $\mathrm{kcal} / \mathrm{mole}$.

By comparing these values with the standard free energies resulting from our solubility measurements, a striking agreement is apparent (Table 3 ).

\begin{tabular}{lcc}
\hline Solvent & $\begin{array}{c}\Delta G^{0} \\
\text { (experimental) }\end{array}$ & $\begin{array}{c}\frac{1}{4} \text { VASLOw, } \\
\text { energies }\end{array}$ \\
\hline $\mathrm{LiNO}_{3}$ & -5.7 & $-(4.7 \div 6.1)$ \\
$\mathrm{NaNO}_{3}$ & -4.0 & $-(3.5 \div 4.2)$ \\
$\mathrm{KNO}_{3}$ & -3.1 & $-(2.7 \div 3.1)$ \\
\hline
\end{tabular}

Table 3.

\begin{tabular}{lcccccc}
\hline \multicolumn{1}{c}{ Solvent } & $K\left(C_{\mathrm{d}} / C_{\mathrm{g}}\right)$ & $\Delta G^{0}$ & $\overline{\Delta H}$ & $\Delta S=\overline{\Delta H} / T$ & $\Delta S_{1}$ & $\Delta S_{2}$ \\
\hline $\mathrm{LiNO}_{3}$ & 200.8 & -5.7 & -12.5 & -23.2 & -10.5 & -12.7 \\
$\mathrm{NaNO}_{3}(+)$ & 41.7 & -4.0 & -9.9 & -18.4 & -7.4 & -11.0 \\
$\mathrm{KNO}_{3}(+)$ & 18.6 & -3.1 & -8.1 & -15.0 & -5.8 & -9.2 \\
\hline
\end{tabular}

Extrapolated values.

${ }^{7}$ F. VAslow, J. Phys. Chem. 67, 2773 [1963].
Table 2.

8 D. M. Ritson and J. B. Hasted, J. Chem. Phys. 16, 11 [1948]. 
Therefore, it seems reasonable to conclude that the large solubility of such polar molecules in ionic media is due to the electrostatic bonding ion-dipole, whose energy is proportional to the moment of the dipole.

Further investigations on the solubility of different polar molecules would provide information on the dependence of the solubility on their dipole moments.

The contribution of the energy expended for hole formation - which plays the principal rôle when dealing with rare gases ${ }^{5}-$ is, in the present case, negligible.

\title{
Zur Protonenrelaxation von Wasser an Silikagelen
}

\author{
D. MICHEL \\ Physikalisches Institut der Universität Leipzig, Abteilung Elektronik \\ (Z. Naturforschg. 22 a, 1751-1760 [1967] ; eingegangen am 23. Juni 1967)
}

\begin{abstract}
In most cases the proton relaxation of adsorbed liquids and gases is caused by the proton-proton dipolar interaction and the coupling between protons and paramagnetic impurities (e. g. $\mathrm{Fe}^{3+}$-ions) of the adsorbent. The latter relaxation mechanism, however, has been neglected up till now although in some commercial silica gels it's contribution can be the most important one (see Section 2.2). Consequently, motional phenomena of adsorbed molecules can only be studied by NMR techniques if the relative largeness of these two relaxation rates has been estimated, as can be done by investigating the dependence of proton relaxation-times on the $\mathrm{H} / \mathrm{D}$-ratio. Relaxation-time measurements in the temperature range from $-100^{\circ}$ to $+80^{\circ} \mathrm{C}$ indicate that proton transfers occur between surface hydroxils and adsorbed particles. In a sample of $3 / 4$ statistical monolayer the presence of two different types of water, clusters containing $95 \%$ of the adsorbed molecules with correlation time $\tau_{\mathrm{c} 2}=2.7 \cdot 10^{-10} \mathrm{~s}\left(0^{\circ} \mathrm{C}\right)$, and more individually adsorbed particles with $\tau_{\mathrm{c} 1} \approx 2.3$ $\cdot 10^{-8} \mathrm{~s}\left(0^{\circ} \mathrm{C}\right)$, has been inferred (see Section 2.1$)$.
\end{abstract}

In den bisherigen Arbeiten ${ }^{1-8}$ wird bei der Deutung der Protonenrelaxation von Wasser an Silikagelen stets davon ausgegangen, da $\beta$ die dipolare Wechselwirkung der Protonen untereinander den einzigen Relaxationsmechanismus darstellt. Wegen ihres großen magnetischen Momentes können die nur in geringer Zahl (ca. 0,1\%) in den Adsorbentien vorhandenen paramagnetischen Ionen die Protonenrelaxation so stark beeinflussen, daß die Proton-Ion-Wechselwirkung den dominierenden Relaxationsmechanismus darstellt ${ }^{9}$. Da die Relaxationsraten Produkte aus Korrelationszeiten und Wechselwirkungsenergien darstellen, sind bei einer falschen Annahme über die Größe des zweiten Faktors die berechneten Bewegungsparameter mit einem großen Fehler behaftet. Aus diesem Grunde werden Untersuchungen an Silikagelen nahegelegt, bei denen die Größe der einzelnen Anteile an den Relaxationsraten bekannt ist.

1 J. R. Zimmermann, B. G. Holmes u. J. A. Lasater, J. Phys. Chem. 60, 1157 [1956].

2 J. R. Zimmerman u. W. E. Brittin, J. Phys. Chem. 61, 1328 [1957].

3 J. R. Zimmerman u. J. A. Lasater, J. Phys. Chem. 62, 1157 [1958].

4 D. E.Woessner u. J. R. Zimmerman, J. Phys. Chem. 63, 1590 [1963].
Das Verhalten von Wasser, das an Silikagelen adsorbiert ist, wurde von Zimmerman und Mitarbeitern ${ }^{1-3}$ und Woessner ${ }^{4,5}$ mit Hilfe der kernmagnetischen Resonanz ausgiebig untersucht. Die an technischen Silikagelen durchgeführten Experimente ${ }^{1,3}$ zeigen, daß die adsorbierten Wassermoleküle in zwei Phasen vorliegen, die durch unterschiedliche Kernspinrelaxationszeiten charakterisiert werden. Zwischen den beiden Bereichen besteht ein Austausch der Protonen, die Aufenthaltszeit eines Protons in einer Phase beträgt bei Zimmertemperatur etwa $1 \mathrm{~ms}^{2}$. Die Arbeiten ${ }^{4,5}$ befassen sich mit der Temperaturabhängigkeit der Protonenrelaxationszeiten von Wasser an einem sehr reinen Silikagel, das aus Äthylorthosilikat hergestellt wurde. In ${ }^{5}$ werden die Untersuchungen von ${ }^{4}$ auf einen größeren Temperaturbereich von $-80{ }^{\circ} \mathrm{C}$ bis $+100{ }^{\circ} \mathrm{C}$ ausgedehnt. Die transversale Relaxationsfunktion besteht auch hier aus zwei Exponentialkurven, deren Zeitkonstan-

5 D. E. Woessner, J. Chem. Phys. 39, 2783 [1963].

6 W. I. Kwliwidse, N. M. IJewskaja, T. S. Jegorowa, W. F. Kiselew u. N. D. Sokolow, Kinetika i Kataliz 3, 91 [1962].

7 W. I. KwLIwIDSE, Dokl. Akad. Nauk USSR 157, 158 [1964].

8 M. M. Egorow, W. I. Kwliwidse, W. F. Kiselew u. K. G. Krassilnikow, Kolloid-Z. u. Z. Polymere 212, 126 [1966].

9 D. Michel, Z. Naturforschg. 21 a, 366 [1966]. 